\title{
Kaliningrad, the Suwalki gap and Russia's ambitions in the Baltic Region
}

\author{
Viljar Veebel \\ Department of Strategic Studies, Baltic Defence College \\ Estonia \\ Viljar.Veebel@ut.ee \\ Zdzislaw Sliwa \\ Department of Strategic Studies, Baltic Defence College \\ Estonia \\ Zdzislaw.Sliwa@baltdefcol.org
}

Abstract. The current study is motivated by the special role of the Kaliningrad region for both Russia and the NATO Alliance. The aim of the study is to analyse how likely is the outbreak of conflict in the Suwalki gap; which factors either hinder or support the escalation of the tensions between Russia and the Alliance in the region. Both the NATO Alliance and Russia have different advantages and disadvantages with respect to any future escalation in the Suwalki corridor and the Kaliningrad region. The main weakness of NATO is its reliance on public opinion, which limits its ability to counter Russian escalation. Conceptually, at least, the Alliance has much deeper pockets, although it is an entirely different matter whether the superiority of resources could be realized in practice. Russia enjoys a public affairs advantage in that it has few requirements to justify its military actions, which may allow it to outlast NATO in a conventional-force brinkmanship scenario despite having many fewer resources. However Baltic States as well European Union should keep in mind that additional force building and deterrence initiatives can lead to escalation and strategic confrontation with Russia, which would bring devastating social and economic consequences for region.

Keywords: NATO, Russia, Kaliningrad, Suwalki, conflict

JEL Classification: F1, F5, P4 


\section{INTRODUCTION}

Recent events in Ukraine, and Russia's geopolitical ambitions have revealed Russia's intentions to destabilise the current security environment in the former Soviet bloc area. Furthermore, Russia's decision to withdraw from the Treaty on Conventional Armed Forces in Europe in 2015 and its constant mobilisation of national military forces close to NATO's eastern flank give cause for growing concern among military and civilian authorities in the Western countries. Among other worrying matters, the Baltic countries feel especially threatened by the possibility that Russia could isolate the Baltic region from its Western allies.

The possible isolation of the Baltic region is linked to the so-called "Suwalki gap" and the geostrategic location of the Kaliningrad region. The Kaliningrad region has historically belonged to East Prussia, but it was annexed by the Soviet Union after World War II and operates now as a federal subject of the Russian Federation, although it is completely separated from Russian mainland (see Sukhankin, this volume, for more). The Suwalki gap or corridor - about 110-115 kilometre wide land border between Lithuania and Poland - connects Kaliningrad with Belarus, Russia's long-standing ally in the region. In fact, all the land access connections between Russia and Kaliningrad pass through the Suwalki gap, and Russia's citizens have a visa waiver arrangement for passing through the area.

The current study is motivated by the special role of the Kaliningrad region for both Russia and the NATO Alliance. The aim of the study is to discuss how likely is the conflict in the Suwalki gap; which factors either hinder or support the escalation of the tensions between Russia and the Alliance in the region; and how far the potential conflict could go should it break out in the future.

The following study provides first a detailed descriptive overview of the Suwalki gap. The article then considers the strategic logic behind possible conflict escalation in the region by weighting the factors that either hinder or support the outburst of the conflict between Russia and the Alliance in Kaliningrad and Suwalki gap. The final part of study will focus on suggestions in terms of NATO responses to Russia's Baltic ambitions.

\section{THE SUWALKI GAP: A DESCRIPTIVE OVERVIEW}

In the academic community, the Kaliningrad region and the Suwalki gap as a research topic have been covered by many authors, especially in the early 2000s before the EU Eastern Enlargement. Recently, some think-tanks and researchers have produced reports and studies on the vulnerability of the region in terms of leaving the Baltic countries in military isolation. Just to name a few, Sirutavičius and Stanytė-Toločkiene (2002) focus on Russia's main strategies for Kaliningrad. The report of the RAND Corporation (Shlapak and Johnson 2016) discusses the practical role of the Kaliningrad region in putting pressure on the Baltic countries. Various authors have contributed to the book "The Kaliningrad Challenge: Options and Recommendations" (see, Birkenbach \& Wellmann, 2003) which covers security-related issues, economic and social aspects, identity-building in the region, possibilities for cooperation, and more. Ivanauskas, Keršanskas and Kasčiunnas (2017) analyse the role of the Kaliningrad region in Russia's relations with Lithuania, the EU and the NATO Alliance in terms of both "hard" and "soft" security, and so on. The current study contributes to the academic literature by providing a more general understanding on theoretical logic behind the potential outbreak of the conflict in the Suwalki corridor, on the one hand, and on a more complex approach to the solutions of how to avoid further escalation of the conflict in the Suwalki corridor, on the other hand.

The aim of Russia's well-targeted actions in the region is to delegitimize the NATO Alliance and, furthermore, to challenge the current international security order and to replace it with the new one, where Russia has significantly greater authority and influence (Veebel, 2018). In a nutshell, Russia is ready to 
systematically and gradually - as much as the country's budget allows - increase tensions in the areas near Russia's mainland with historical and symbolic value to maintain and increase internal support. Internally, Russian expansionism is framed as an appropriate response to the supposedly imperialist actions of NATO and the US.

From Russia's perspective, both Kaliningrad and Suwalki corridor constitutes a favourable place where Russia's ability to mobilise in time of peace and to escalate the conflict is greater than that of the NATO Alliance. The country has at most three armies available in the Western Military District. Furthermore, Russia also has a clear advantage in mobilizing additional deployment up to additional 20 brigades in time of peace, as well as in contributing from greater territorial depth and more alternatives in terms of logistical routes than the NATO forces in the Baltic countries and close to Suwalki. Since Russia could move military resources more easily and more extensively in this region in comparison with the capabilities of the NATO Alliance, it would be reasonable to assume that the escalation of the conflict would be most likely favourable for Russia, as far as direct conventional conflict is out of the question.

For the NATO Alliance, all scenarios, from increasing regional security to the actual conventional mobilization, are marked by serious complications. Additional deployments in the region under the auspices of increasing security would be both costly and institutionally complicated. For example, the former commander of the US Army in Europe and retired Lieutenant General in the US Army Ben Hodges has suggested many reasons (Hodges 2018) why Poland's recent offer to establish permanent US military presence in Poland (Zemla \& Turecki 2018) would undermine the cohesion of the members of the NATO Alliance. Furthermore, in real terms, this step would not even contribute to the regional conventional balance which would actually need additional 18 brigades instead of merely a single brigade. Should the Alliance still decide for the latter, it would allow Russia to both maintain its moral "upper hand" in the region and to justify its additional deployments, based on the argument that NATO is both aggressive and offensive.

Economic conditions clearly set significant restrictions on Russia in terms of choosing between escalation or de-escalation of the conflict. The size of the Russian economy (its nominal GDP in 2017 was 1.72 billion USD) is smaller than that of Germany, the United Kingdom, France and Italy (respectively 4.21 billion USD, 2.94 billion USD, 2.93 billion USD and 2.18 billion USD in 2017) and basically on the same level as the nominal GDP of Spain (1.51 billion USD in 2017)(IMF 2018). Limited economic resources have forced Russia to set priorities, as not enough resources are available for "half-hard" initiatives. Under these circumstances, Russia clearly pursues a highly concentrated security and defence policy, without any possibility of hesitation, morality or questionable efficiency. However, limited resources have a central role in Russia's coercive bargaining, as assets may end before motivation (Altman 2018, 58-60)

For both parties to the potential confrontation, Russia and the NATO Alliance, the "costs" of the conflict in the Suwalki and Kaliningrad are first and foremost determined by geographical and ethnic factors. The most extensive study covering the geographical aspect is by Elak and Šliwa (2016), who argues that the terrain of the Suwalki corridor supports particularly defensive operations. The potential "costs" associated with geographical factors would most likely be remarkable for both opponents, because specific capabilities and tactics will be needed to conduct military operations, and at the same time, the outcome of the operations will be unpredictable. However, what should worry the Alliance is that, due to geographical characteristics, it would be difficult to regain control over the Suwalki gap if the area is lost.

As far as the ethnic factor in the Suwalki corridor is concerned, at first sight, Russia seems to have a disadvantage. Elak and Šliwa (2016) point out that the population in the Suwalki corridor covers mainly Polish nationals (about 2 million people), whereas the ethnic minorities in the region are Ukrainians $(65,000)$ and Lithuanians (about 25,000). There are only 11,000 Russians living in the Suwalki corridor. Thus, there is no significant Russian-minded community living in the area of Suwalki corridor that could be used by 
Russia in a similar way Russia did during the annexation of the Crimea, allowing Russia to diminish the "costs" of the aggression. However, it has been argued that still a potential Russian influence exists in Suwalki, referring to Russia's attempts to attract Polish citizens to take part in militarised tournaments and other events, e.g. in the International Paintball Tournament "Road to Victory" which has in various years involved also participants from Poland (Grigas 2016). Also some Lithuanian radicals, most likely supported by Russia, have raised claims in social media that Lithuania should regain the Suwalki corridor from Poland (Ibid.).

Another issue is whether the population of Kaliningrad could be exploited by Russia to initiate conflict in the region by relying, for example, on a "near neighbourhood"-argument or through broad public support in this region. The majority of the population living in Kaliningrad region are, of course, Russian citizens (about $95 \%$ of total population or 896,000 people based on the survey from 2010)(Russian Federal Statistical Service, (2017)). At the first glance, this aspect seems to speak in favour of Russia and to diminish the potential "costs" of the conflict, e.g. costs related to information warfare justifying and searching support for Russia's aggressive actions in the region.

Furthermore, despite some expectations in the international arena that there is a potential for an independent regional identity to be formulated in the Kaliningrad region, recent developments reflect rather the opposite. Over the last 10-15 years, the share of people living in Kaliningrad and identifying themselves as "citizens of Russia" is significantly increasing: the share of respondents who considered themselves as "citizens of Russia" as a first choice was 24.6\% in 2001, 32.5\% in 2004, 36\% in 2011 and 41.4\% in 2015\% (Kojala \& Keršanskas, 2016).

However, two aspects could still work against Russia when exploiting the ethnic factor in a potential confrontation in the Kaliningrad region. First, previously the region has seriously challenged the decisions of Russia's political elite. For example, massive protests against the politics of the Russian political elite took place in Kaliningrad in 2010, and Russia's ruling party "United Russia" received no seats in the local council elections in 2015 (see, Kojala \& Keršanskas, 2016). Second, although the share of ethnic minorities in the Kaliningrad region is marginal considering their share in total population, due to historical background the ethnic composition of the population in the Kaliningrad regions is diversified, covering many groups of ethnic minorities (see Figure 1, which illustrates the biggest ethnic minorities in the Kaliningrad region). This means that it would be rather difficult for Russia to address and exploit the ethnic minorities in the Kaliningrad region as one single group in case of the conflict.

Next, to geographic and ethnic factors, the level of economic development of the Kaliningrad region together with the region's economic outlook indicates that economically the Kaliningrad region is rather insignificant for Russia. Since 1996, the Kaliningrad region has enjoyed the privileges of a "special economic zone (SEZ)" which allowed the region to trade tax-free and to pay no duties to Russia. Thanks to this opportunity, the region has in the early 2000s and before the economic crisis shown fastest annual growth numbers among Russia's regions (Palet, 2014). In 2006, the SEZ was updated with the new federal law, allowing enterprises to have the right to export goods manufactured on the base of imported components to the territory of Russia without paying any duties and taxes until April 2016, and the right to export such products until 2031. These privileges have expired amid Western sanctions on Russia, and it was estimated that the end of the special economic zone is expected to have a negative impact on at least 785 local companies that currently employ $24 \%$ of local workforce (Veebel, 2019). No official data on economic development at the regional level has been published yet. 


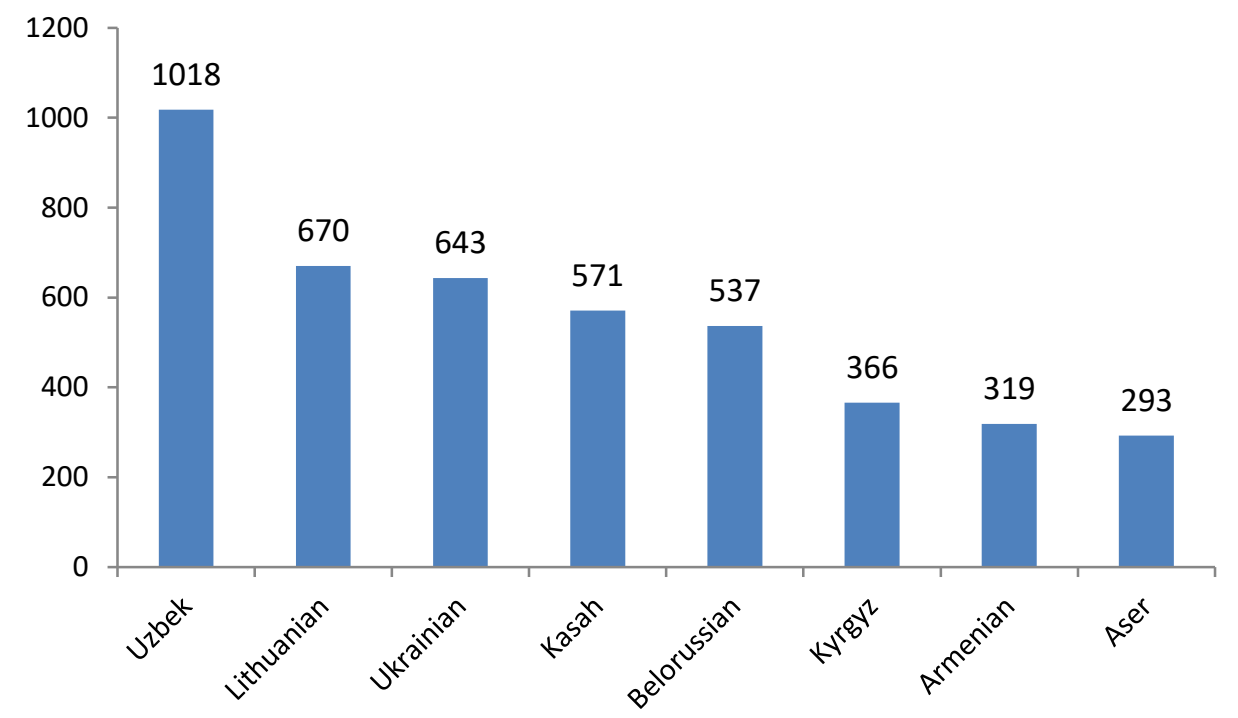

Figure 1. Biggest ethnic minorities in the Kaliningrad region (in 2010)

Source: Russian Federal Statistical Service (2017)

Despite all the privileges the Kaliningrad region has gained, the federal subject has recently shown fluctuating growth numbers, and the region's nominal GDP covers less than 1\% of Russia's total nominal GDP (see, Table 1). The average wage in the Kaliningrad region is significantly below Russia's average wage (the region actually belongs to the three regions in the Severo-Zapadnyi Federal Okrug with the lowest average wage) and the share of population living below the minimum subsistence figure in the Kaliningrad region (\% of total population in the region) is higher than in Russia overall (see, also Table 1).

Therefore, the "costs" of giving up the Kaliningrad region in economic terms with the hypothetical aim to avoid the conflict with the NATO Alliance would be rather insignificant for Russia. The only economic argument why Russia could prefer to "keep" the Kaliningrad region is that the Kaliningrad Sea Commercial Port is the only ice-free Russian port on the Baltic Sea, as well as the largest regional port complex in terms of volume, technical support and services granted to the cargo owners (Veebel and Markus 2018). Also, major shipping and fishing industries are located in Kaliningrad.

To sum up, both geographical conditions in Suwalki corridor and the ethnic composition of both the Suwalki Gap and the Kaliningrad region make it definitely difficult for Russia to achieve a rapid dominance in the regional conflict, as happened in Ukraine some years ago. In economic terms, the "sacrifice" of the Kaliningrad region to the West to avoid the escalation of the conflict could - rationally thinking - also be under consideration, assuming that the region's economic potential is insignificant for Russia. Furthermore, next to these arguments Russia has other options of how to put pressure on the Baltic countries or even to isolate them, without triggering expensive military conflict with uncertain outcome. Russia's aggressive behaviour against Estonia in 2007 is a good illustration of its methods in putting pressure on the neighbouring countries. Namely, when in 2007 Estonia removed a memorial dedicated to Soviet soldiers, Russia responded aggressively, deploying a wide array of measures to damage Estonia. Russian politicians arrived in Estonia to "rile things up" while Russian-language websites offered instructions on how to attack Estonian websites. In addition, Russia's Federation Council called on its government to cut off diplomatic relations with Estonia. The Estonian embassy in Moscow was blockaded by Kremlin-sponsored Russian youth movements. Russian officials called for boycotts against Estonian productions. Trade on the RussianEstonian border ground to a halt as truck traffic at the main bridge into Estonia was blocked and the delivery 
of oil, coal and petroleum products to Estonia was cut off. Cyberattacks were accompanied by the psychological onslaught, etc. (see, Veebel 2015).

Table 1

Comparison of selected socio-economic indicators during the period 2010-2017: Russia versus the

Kaliningrad region

\begin{tabular}{|c|c|c|c|c|c|c|c|c|}
\hline & 2010 & 2011 & 2012 & 2013 & 2014 & 2015 & & \\
\hline $\begin{array}{l}\text { Nominal GDP (million } \\
\text { RUB): Russia total } \\
\end{array}$ & 37687768 & 45392277 & 49926069 & 54013599 & 58900652 & 64997039 & & \\
\hline \multirow{2}{*}{$\begin{array}{l}\text { Nominal GDP (million } \\
\text { RUN): Kaliningrad } \\
\text { region }\end{array}$} & 195749,1 & 241004,8 & 265361,2 & 277362,6 & 306232,8 & 328760 & & \\
\hline & 2010 & 2011 & 2012 & 2013 & 2014 & 2015 & & \\
\hline \multirow{2}{*}{\begin{tabular}{|l|} 
Share of Kaliningrad \\
region in total nominal \\
GDP of Russia (\%)
\end{tabular}} & 0,52 & 0,53 & 0,53 & 0,51 & 0,52 & 0,51 & & \\
\hline & & 2011 & 2012 & 2013 & 2014 & 2015 & & \\
\hline $\begin{array}{l}\text { The annual growth rate } \\
\text { of nominal GDP: Russia } \\
\text { total } \% \text { ( ) }\end{array}$ & & 20,44 & 9,99 & 8,19 & 9,055 & 10,35 & & \\
\hline \multirow{3}{*}{\begin{tabular}{|l|} 
Annual growth rate of \\
nominal GDP: \\
Kaliningrad region (\%) \\
\end{tabular}} & & 23,12 & 10,11 & 4,52 & 10,41 & 7,36 & & \\
\hline & & & & & & & & \\
\hline & & & & 2013 & 2014 & 2015 & 2016 & 2017 \\
\hline $\begin{array}{l}\text { Average monthly wage } \\
\text { (RUB): Russia total }\end{array}$ & & & & 25928,2 & 27767 & 30467 & 30747 & 31477 \\
\hline \multirow{2}{*}{$\begin{array}{l}\text { Average monthly wage } \\
\text { (RUB): Kaliningrad } \\
\text { region }\end{array}$} & & & & 20641,8 & 23117 & 25875 & 25913 & 26683 \\
\hline & & 2011 & 2012 & 2013 & 2014 & 2015 & 2016 & 2017 \\
\hline $\begin{array}{l}\text { Share of people living } \\
\text { below the minimum } \\
\text { subsistence figure: } \\
\text { Russia total (\% of the } \\
\text { total population) }\end{array}$ & & 12,7 & 10,7 & 10,8 & 11,2 & 13,3 & 13,3 & 13,2 \\
\hline $\begin{array}{l}\text { Share of people living } \\
\text { below the minimum } \\
\text { subsistence figure: } \\
\text { Kaliningrad region (\% } \\
\text { of the total population } \\
\text { in the region) }\end{array}$ & & 12,7 & 10,8 & 12,4 & 12,1 & 13,4 & 14 & 14,1 \\
\hline
\end{tabular}

Overall, these arguments speak in favour of the idea that the outbreak of the expensive military conflict with an uncertain outcome in the Kaliningrad region and the Suwalki corridor would actually not be in the rational interests of Russia if seen in regional theatre level and not to count assets already spent for fuelling the escalation. Basically the same applies to the NATO Alliance who also has to struggle with difficult geographical and logistical conditions should the conflict break out in Suwalki gap. 


\section{THE SUWALKI GAP AND KALININGRAD: RUSSIAN AND NATO'S STRATEGIC CONSIDERATIONS}

From a purely military perspective, the geostrategic location of the Kaliningrad region and Suwalki corridor is associated both with opportunities and challenges from Russia's perspective. On the one hand, it allows early warning and forward area air defence options in combination with units from the mainland, especially from the Western Military District. Furthermore, the Baltic Fleet with the headquarter in Kaliningrad possesses bases allowing control over the central Baltic Sea region and access to the Gulf of Finland influencing not only the Baltic countries but also Finland and Sweden's security and freedom of manoeuvre. On the other hand, the location of Kaliningrad as a specific federal subject of the Russian Federation poses a serious problem for Russia itself as due to cultural notions of "national pride", Russia has to be proactive and to constantly expose its military capabilities in the Kaliningrad region, although in practical terms there is no need for that as the NATO Alliance is not threatening to take over Russia's enclave.

From the Alliance's perspective, many military and civilian experts have pointed to the threat that due to the Kaliningrad region and the "Suwalki corridor" the Baltic countries could remain isolated from the Allies in case of a conflict. For example, Lieutenant General Ben Hodges has warned that "Kaliningrad now has the ability to deny access of our [US] Navy or any NATO Navy to come to the Baltic Sea. From Kaliningrad, Russia can stop entering into the Baltic Sea, and there we have three NATO allies - Estonia, Latvia and Lithuania" (The US General..., 2015). According to the report of the RAND Corporation, in case of hostilities "NATO forces would have to transit the 'Kaliningrad corridor,' a 110- to 150-km-wide stretch of territory between the Russian enclave and Belarus that could be subject to long-range artillery and flank attacks from both sides and would require a commitment of (scarce) NATO forces to secure" (Shlapak \& Johnson, 2016). The Chief of the Estonian Defence Forces, General Riho Terras has stated that "in the long term Russia's wish is to bring the Baltic Sea and the passages leading to it more and more under its control and to control it much like it does the Black Sea" (ERR 2016). Also the former Minister of Defence, Hannes Hanso has pointed to the need "to keep our eyes open in the air, on the water, and everywhere else" (Ibid.). Similar views have been shared also by General (ret) Wesley Clark, General (ret) Sir Richard Shirreff, the current Minister of Defence of Estonia Jüri Luik (Clarke et al., 2016), and others. Furthermore, the analyses of international think-tanks like the RAND Corporation (Shlapak \& Johnson, 2016), the Potomac Foundation, Chatham House, and of regional research centres such as the Center for Security and Strategic Research (Praks, 2015) have expressed concerns over the growing security threats posed by Russia for many years already.

Up to now, both parties to the confrontation have definitely sent each other "costly signals" in material terms. Russia has constantly observed NATO's attempts to enlarge and, in the words of one commenter, "although Russia was not able to prevent NATO enlargement into Visegrad its leaders have informed the West with unmistaken clarity that they view the Baltic membership in NATO as 'red line' that should not be crossed and will consider any NATO expansion into that region as direct threat to Russia's vital national interests" (Veebel \& Ploom, 2018). NATO has started some initiatives such as the establishment of the Baltic Air Policing mission in 2004 to guard the airspace over the three nations, as well as joint exercises, investment into BALTNET (Baltic Air Surveillance Network and Control System) and military exchanges. Russia has constantly criticised these initiatives. As a response, Russian armed forces conducted large-scale snap exercises, violated airspace, and conducted navy manoeuvres close to its exclusive economic zones to show how considerable capabilities it has to face NATO. The "answers" were, for example, military exercises Zapad 2009, Zapad 2013 and Zapad 2017 in the Western military district of Russia which were basically interpreted as a political manifesto against the presence of NATO in Eastern Europe by the 
Western experts. It is obvious that systematic military exercises in all regular military districts of Russia ${ }^{1}$ are the country's reaction to the NATO military exercises², e.g. the military exercise Zapad 2013 was a response to NATO's exercises Baltic Host 2013 and Steadfast Jazz 2013. The experts have labelled Russia's response to NATO's activities as an example of "Kremlin's muscle-flexing, designed to escalate concerns of NATO and especially Eastern Europe and the three Baltic countries" (Šliwa, 2016). However, viewed objectively the process is rather mutual, where both sides try to deter the opponent with complex military exercises.

\section{CONCLUSIONS: HOW TO AVOID ESCALATION}

To sum up, both the NATO Alliance and Russia have different advantages and disadvantages with respect to any future escalation in the Suwalki corridor and the Kaliningrad region. The main weakness of NATO is its reliance on public opinion, which limits its ability to counter Russian escalation. Conceptually, at least, the Alliance has much deeper pockets, although it is an entirely different matter whether the superiority of resources could be realized in practice. Russia enjoys a public affairs advantage in that it has few requirements to justify its military actions, which may allow it to outlast NATO in a conventional-force brinkmanship scenario despite having many fewer resources.

Unhappily and despite the apparent irrationality for all parties, the dynamics of the current relations between Russia and the NATO Alliance clearly point toward escalation. Today, Russia is accusing the Alliance of provocations and instability in the neighbourhood regions of Russia. To quote a recent statement expressed by Vladimir Putin:

NATO is building up its military potential near our borders and attempts are being made to halt integration processes with Russia's participation, provoke new and stir up old conflicts in the post-Soviet space and in regions neighbouring on Russia, with all the ensuing consequences - military and political instability, the growth of smuggling and crime and acute humanitarian problems. (see, e.g. Press'TV 2018)

In response, NATO stated that Russia is contributing to the increasingly unpredictable and unstable Euro-Atlantic security environment, and "in response, NATO has taken defensive measures to protect and assure its members and will continue to do so as long as necessary" (NATO 2016). The same applies to the Alliance's response to the latest military exercises Zapad 2017, when it was promised by the Alliance to "continue to be vigilant and ready to act if needed" (Johnson 2017). The view has been expressed that the Alliance has to stick to this approach, should Russia continue "its military build-up in the Western Military District and its programme of provocative and destabilising exercise activities" (Ibid.).

It seems that although both parties to the confrontation have sent each other "costly signals", the current deterrence strategy is not working. Conducting more and more complex military exercises and increasing military capabilities in the Suwalki corridor and the Kaliningrad region have not made the opponent to be more afraid; on the contrary, it has forced both sides to further mobilise their resources. This applies particularly to Russia who every time after the Alliance has taken its next step seems to be more and more motivated to proactively expose its military capabilities. In this sense, the constant increase in the number of military forces and capabilities in the Suwalki corridor and the Kaliningrad region seems to be irrational, since it does not bring the expected results in terms of de-escalating potential military tensions in the area. Today, in military terms the conventional imbalance in the Baltic region is 1:8 in favour of Russia

${ }^{1}$ For a comprehensive overview of the military operations conducted by Russia in 2008-2018 and their military dimension, see, e.g. Johnson (2017).

${ }^{2}$ For example, the overview of the key NATO and Allied Multinational exercises in 2017 is available in NATO (2017). 
which means that in real terms 18 additional brigades are needed to preliminary equalise regional conventional capabilities. In this light, the situation is already relatively hopeless for the Western countries, meaning that NATO should deploy 18 brigades, to attain a balance, plus additional brigades, to gain the initiative. However, there is neither enough logistics available in the Baltic countries to achieve this, nor has the NATO Alliance enough capabilities to do it, not to mention the lack of motivation to mobilise additional resources in time of peace.

As far as "the more, the better" principle is concerned, in military circles the discussion on mutual deterrence has also focused on the anti-access/area-denial capabilities (A2/AD), covering long-range capabilities both to prevent or degrade an advancing opponents ability to enter an operational area, and to limit opponents freedom of actions within the operational area (see, e.g. Williams 2017 as well as the other articles in this issue). It has been estimated that Russia owns a seemingly impressive array of long-range A2/AD systems that could interfere NATO 's activities to conduct operations mostly in the Baltic Sea region, but also in the Black Sea, eastern Mediterranean and Barents Sea region (Ibid.). The threats stemming from Russia s multifaceted abilities have been stressed also by General (ret) Wesley Clark, General (ret) Sir Richard Shirreff and Jüri Luik, the current Minister of Defence of Estonia, arguing that:

Russia would be capable not just of sealing off the Baltic states in the "bubble" that covers air, sea and land dimensions, but also of fiercely contesting other spaces of critical importance to military operations - in the electromagnetic spectrum, cyberspace, and even outer space (by using anti-satellite capabilities). (Clark et al 2016)

In addition, similar opinions are shared by General (ret.) Sir Richard Barrons, who argues that Russia could be ready for action within 48 hours and "some land and control of airspace and territorial waters could be lost before NATO's 28 member states had even agreed how to respond" (Haynes 2016). Likewise, senior NATO officials, including General Philip Breedlove, the supreme allied commander Europe, and General Frank Gorenc, commander allied air command, have raised concerns over A2/AD in a European context during 2015 (Barrie 2016). In this way, the NATO Alliance clearly feels threatened by the reinforcement of the Kaliningrad Oblast, as well as occupation of the Crimea peninsula and development of Arctic capabilities, which all contribute to the enhancement of Russia's A2/AD shield. At the same time, there exists no clear threat assessment whether the activities in Kaliningrad region and Suwalki corridor are in accordance with the idea of the A2/AD capabilities in the first place. So it could easily happen that with all the Russia's propaganda and the informational disorientation, Russia has managed to deter the Alliance using the conceptual framework the Western countries are familiar with. At least the current rhetoric of the members of the Western military community refers to the situation where Western military circles are busy with self-deterrence and not focusing on the more realistic threats in the Kaliningrad region, such as Russias potential influence in Suwalki in the form of Russia's attempts to attract Polish citizens to take part in militarised tournaments and other events, or supporting Lithuanian radicals to raise claims that Lithuania should regain the Suwalki corridor from Poland.

Unfortunately, military conflict between Russia and the NATO Alliances cannot be fully excluded as a possibility in the near term. In principle, the Alliance members may choose to push Russia to go to the last line of escalation or else may force Russia either to surrender in economic terms or to get involved in actual conflict. Although costly, these scenarios would almost certainly mean the end of the Vladimir Putin's political regime. Alternately, the NATO Alliance could elect to ignore Russia's attempts to escalate the conflict around Kaliningrad and the Suwalki corridor. This de-strategizing of the region may be reinforced by escalating conflict somewhere else, e.g. in Libya or the Artic region. If the Western countries are not 
intending to go to the last line of escalation, there is no sense in deploying additional battalions to the Baltic/Kaliningrad region.

Another issue is, of course, whether in real terms the conflict breaks out in Suwalki corridor or somewhere else. In this light, a glance at the possible escalation of the conflict is fully justified. Šliwa, Veebel and Lebrun (2018) have suggested that both the "hybrid warfare"-scenario and the use of minorities, similar to that what happened in Ukraine, would be unlikely in the Suwalki corridor, because "little green men" would be noticed early, should the conflict break out there.

Under these circumstances, it would be fully rational to assume that both parties to the conflict could be ready to find a more or less satisfying peaceful solution instead of escalating the conflict. Until now, the opponents in the Suwalki corridor have sent each other costly signals, but instead of communicating the willingness to stop fighting, the signals were oriented to express the determination to fight. As unexpected as it might seem, the fully rational solution in this light would be for both parties to the conflict to find a common ground which would be profitable for both sides. The NATO Alliance will most likely be interested in neutralizing Russia's aggressive regional ambitions and in stabilizing the current security situation around the world without being directly involved in military conflicts. Whereas Russia's political elite is using constant tensions with its neighbouring countries and with the Alliance to find broad public support at the domestic level, these same elites would most likely be interested in a solution that would help the country's government to show the people of Russia that the country is accepted or even respected in the international political arena. Considering the waves of public protests against the corruption of Russia's political elite in recent years all over the country, the pressure on Russia's government "to do something" becomes more and more intense, and the time frame for making the decisions becomes more and more narrow.

In this sense, the common ground for both parties to the conflict lies in promoting mutual long-term strategic partnership. This would allow both Russia and NATO to achieve their aims without getting in a direct military conflict. The keyword hereby is "long-term", referring to the well-designed and multifaceted strategy which includes mutually beneficial elements, but also restrictions and requirements which need to be followed for the long-term partnership to work. In principle, this is very similar to "the carrot and the stick"-approach used by the EU.

It is obvious that today Russia will not take the initiative to find a common ground with the NATO Alliance. This means that "the carrot" needs to be something very special for Russia, something that would allow its elites to clearly signal to their domestic audiences that Russian authority and influence are increasing regionally and globally. Developing such a concession is certainly going to be tricky. To succeed, NATO would need to allow Russia's political elite to step back in domestic anti-NATO rhetoric or even to accept of being domestically labelled the "chicken", without losing broad public support. Second, the Alliance's long-term solution needs to be accepted by all allies of NATO, both big and small. However, this latter aspect could be very difficult, assuming that security concerns and the perceptions of the Allies on security are very different.

It is clear that this type of solution is not going to be reached overnight, but it needs both good will of the parties to the conflict as well as a neutral platform to conduct strategic discussions. In the short term, what the Alliance could do already today is to change the overall balance of the conflict for Russia and to push the country to opt for peaceful solution instead of the conflict escalation. The first thing to do here is to build-up strategic relations also with Russia's allies. In the Kaliningrad region, this applies particularly to Belarus. With the recent military exercise Zapad 2017, Russia proved its interest in preserving its greater authority in its relationship with Belarus. It was also a message to the Western countries that the Belarus is and will be in the area of influence of the Russian Federation. Most likely "the carrots" for both Russia and Belarus are similar based on the assumption that both political regimes are currently treated as pariahs in 
the international arena and are relying on public domestic support. Thus, building long-term strategic relations with Belarus could work as a test-area for the NATO Alliance.

Last but not least, for the Western countries it is highly important to make the overall decision and to commit to its decision as fast as possible, since whatever subsequent changes later on will be very costly. So, if NATO is committed to go "all in" in the Baltic region, it should decisively deploy to the area without paying attention on Moscow's complains. The more unexpected and disproportional are the deployments of convincing $\mathrm{A} 2 \mathrm{AD}$ capabilities and other resources, the faster the game reaches its end. However, if NATO is not committed to "go all in" with the strategic confrontation with Russia in the Suwalki corridor and in Kaliningrad, there is no point to deploy additional assets in the region or to pay any attention on Russia's rhetoric. On the contrary, the stakes should be lowered, possibly by creating tensions other regions in the hope that this will lead Russia to think that they have missed something. Russia could be convinced that real strategic gains are to be found elsewhere, either in the Arctic region, in Libya or in Syria. Whatever the costs, NATO should prevent Russia in putting new bids on the table in the Baltic region, which would make leaving the game in the future even more complicated. The regional conflict which at certain moments has grown to become a strategic confrontation should be de-escalated again to the regional level, where risks and rationality are calculated on the basis of the value of regional assets and not global confrontation.

\section{REFERENCES}

Adamowicz, M., \& Machla, A. (2016). Small and Medium Enterprises and the Support Policy of Local Government. Oeconomia Copernicana, 7(3), 405-437. doi: http://dx.doi.org/10.12775/OeC.2016.024

Altman, D. (2018). Advancing without Attacking: The Strategic Game around use of Force. Security Studies, 27(1), 5888.

Andžāns, M., \& Veebel, V. (2017). Deterrence Dilemma in Latvia and Estonia: Finding the Balance between External Military Solidarity and Territorial Defence. Journal on Baltic Security, 3(2), 29-42.

Atkinson, A.B., \& Stiglitz, J.E. (1980). Lectures on Public Economics. London, McGraw Hill.

Ayyagari, M., Beck, T., \& Demirguc-kunt, A. (2007). Small and medium enterprises across the globe. Small Business Economics, 29, 415-434. doi: http://dx.doi.org/10.1596/1813-9450-3127

Barrie, D. (2016). Russia and anti-access/area-denial capabilities. International Institute for Strategic Studies, 08 February 2016. Available: http://www.iiss.org/en/militarybalanceblog/blogsections/2016-629e/february-f0ed/russiaand-anti-access-area-denial-capabilities-9b3e

Beck, T., Demirguc-Kunt, A., \& Martinez Peira, M.S. (2011). Bank financing for SMEs: evidence across countries and bank ownership types. Journal of Financial Services Research, 39, 35-54. doi: 10.1007/s10693-010-0085-4

Berger, A.N., \& Udell, G.F. (2002). Small business credit availability and relationship lending: the importance of bank organizational structure. The Economic Journal, 112(477), 32-53. doi: 10.1111/1468-0297.00682

Berger, A.N., Goldberg, L.G., \& White, L.J. (2001a). The effects of dynamic changes in bank competition on the supply of small business credit. European Financial Review, 5, 115-139.

Berger, A.N., Klapper, L.F., \& Udell, G.F. (2001b). The ability of banks to lend to informationally opaque small business. Journal of Banking and Finance, 25, 2127-2167. doi: 10.1016/S0378-4266(01)00189-3

Berger, A.N., Klapper, L.F., Martinez-Peria, M.S., \& Zaidi. R. (2008). Bank ownership and banking Relationships. Journal of Financial Intermediation, 17, 37-62. doi: 10.1016/j.jfi.2006.11.001

Birkenbach, H.-M., \& Wellmann, C. (eds)(2003). The Kaliningrad Challenge: Options and Recommendations. Kiel Peace Research Series. LIT Verlag Münster.

Chang, C., Liao, G., Yu, X., \& Ni, Z. (2014). Information from lending relationship: evidence from loan defaults in China. Journal of Money, Credit and Banking, 46(6), 1225-1257.

Clark, W., Luik, J., Ramms, E., \& Shirreff, R. (2016). Closing NATO’s Baltic Gap, International Centre for Defence and Security. Tallinn 2016. R. Shirreff, War with Russia, Coronet Books, London 2016.

Clarke, G., Cull, R., Martinez Peria, M.S., \& Sanchez, S.M. (2005). Bank lending to small business in Latin America: Does bank origin matter? Journal of Banking Money, Credit, and Banking, 37, 83-118. 
D’Aurizio, L., Oliveiro, T., \& Romano, L. (2015). Family firms, soft information and bank lending in a financial crisis. Journal of Corporate Finance, 33, 279-292. doi: http://dx.doi.org/10.1016/j.jcorpfin.2015.01.002

Detragiache, E., Tressel, T., \& Gupta, P. (2006). Foreign banks in poor countries: Theory and evidence. IMF Working Paper No. 18. International Monetary Fund, Washington DC.

Dolezal, J., Snajdr, J., Belas, J., \& Vincurova, Z. (2015). Model of the loan process in the context of unrealized income and loss prevention. Journal of International Studies, 8(1), 91-106. doi: 10.14254/2071-8330.2015/8-1/8

Dubravska, M., Mura, L., Kotulic, R., \& Novotny, J. (2015). Internationalization of Entrepreneurship-Motivating Factors: Case Study of the Slovak Republic. Acta Polytechnica Hungarica, 12(5), 121-133.

Elak, L., \& Šliwa, D. (2016). The Suwalki Gap - Nato's Fragile Hot Spot. Zeszyty Naukowe AON, 2 (103).

ERR (2016). Terras: Russia demonstrating wish to control Baltic Sea area. Eesti Rahvusringhääling, 07 October 2016, http:/ / news.err.ee/v/news/2bd72ff4-396e-4e61-897a-d8bfe903e6c8/terras-russia-demonstrating-wish-tocontrol-baltic-sea-area

Fiserova, T., Teply, P., \& Tripe, D. (2015). The performance of foreign-owned banks in the host country economics. Prague Economic Papers, 24(5), 1-24. doi: 10.18267/j.pep.527

Gormley, S., Kanatas, G., \& Venezia, I. (2006). Bank competition in developing countries: does foreign bank entry improve credit access? Mimeo. MIT.

Grigas, A. (2016). NATO’s Vulnerable Link in Europe: Poland's Suwalki Gap. Atlantic Council, 9 February 2016. http://www.atlanticcouncil.org/blogs/natosource/nato-s-vulnerable-link-in-europe-poland-s-suwalki-gap

Haynes, D. (2016). NATO has no plan if Russia invades, warns ex-general. The Times, 19.09.2016, http://www.thetimes.co.uk/article/dh-nato-0nxssn0rr

Hodges, B. (2018). Don't put US bases in Poland. Politico, 6 June 2018. https://www.politico.eu/article/dont-putus-bases-in-poland/

IMF (2018). World Economic Outlook (April 2018). http://www.imf.org/external/datamapper/NGDPD@WEO/OEMDC/ADVEC/WEOWORLD/RUS

Ivanauskas, V., Keršanskas, V., \& Kasčiūnas, L. (2017). Kaliningrad Factor in Lithuanian - Russian Relations: Implications to the Security Issues of Lithuania. The Journal of Military Academy of Lithuania, 15(1), 119-149.

Jimenez, G., Salas, V., \& Saurina, J. (2006). Determinants of collateral. Journal of Financial Economics, 81, $255-281$. doi:10.1016/j.jfineco.2005.06.003

Johnson, D. (2017). ZAPAD 2017 and Euro-Atlantic security. NATO Review Magazine, 14 December 2017. https://www.nato.int/docu/review/2017/also-in-2017/zapad-2017-and-euro-atlantic-security-militaryexercise-strategic-russia/EN/index.htm

Kljucnikov A., Belas, J., Kozubikova, L., \& Pasekova P. (2016).The Entrepreneurial Perception of SME Business Environment Quality in the Czech Republic. Journal of Competitiveness, 8(1), 66-78.

Kojala, L., Keršanskas, V. (2016). (Un)convenient Kaliningrad and Kremlin's relationship. News portaal DELFI, 7 December 2016. https://en.delfi.lt/central-eastern-europe/ unconvenient-kaliningrad-and-kremlinsrelationship.d?id $=73098334$

La Porta, R., Lopez-de-Silances, F., \& Shleifer, A. (2002). Government ownership of commercial banks. Journal of Finance, 57(1), 265-301. doi: 10.1111/1540-6261.00422

Menkhoff, L., Neuberger, D., \& Rungruxsirivorn, O. (2012). Collateral and its substitutes in emerging markets lending. Journal of Banking and Finance, 36, 817-834.

Mian, A. (2003). Foreign, private domestic, and government banks: New evidence from emerging markets. University of Chicago, Mimeo.

Mian, A. (2006). Distance constraints: the limits of foreign lending in poor economics. Journal of Finance, 61(3), 14651505. doi: 10.1111/j.1540-6261.2006.00878.x

NATO (2016). The Secretary General's Annual Report 2015, NATO Brussels 2016.

NATO (2017). Key NATO \& Allied Exercises. https://www.nato.int/nato_static_fl2014/assets/pdf/pdf_2017_05/20170510_1705factsheet_exercises_en.pdf

Nguyen, S., \& Wolfee, S. (2016). Determinants of successful access to bank loans by Vietnamese SMEs: new evidence from the red river delta. Journal of Internet Banking and Commerce, 21(1), 1-23. 
Palet, L. S. (2014). Russia's strongest foothold in Europe: it's not the Ukraine. USA Today, 26 April 2014. https://www.usatoday.com/story/news/world/2014/04/26/ozy-russia-kaliningrad/8194403/

Praks, H. (2015). Hybrid or Not: Deterring and Defeating Russia’s Ways of Warfare in the Baltics - the Case of Estonia. Research Paper No 124, NATO Defence College Rome December 2015.

Russian Federal Statistical Service, (2017) Statistical Data 2010-2017. http://www.gks.ru/wps/wcm/connect/rosstat_main/rosstat/ru/statistics/publications/catalog/doc_1138 623506156

Shlapak, D. A., Johnson, M. W. (2016). Reinforcing Deterrence on NATO's Eastern Flank. RAND Corporation. https://www.rand.org/content/dam/rand/pubs/research_reports/RR1200/RR1253/RAND_RR1253.pdf

Sirutavičius, V., \& Stanytė-Toločkienè, I. (2002). Strategic Importance of Kaliningrad Oblast of the Russian Federation. Lithuanian Annual Strategic Review, 1.

Śliwa, Z. (2013). Zapad 2013: The Russian Armed Forces Flexes its Muscles. Operational Environment Watch, Foreign Military Studies Office (FMSO), Fort Leavenworth 25 September 2013.

Śliwa, Z., Veebel, V., \& Lebrun, M. (2018). Russian Ambitions and Hybrid Modes of Warfare. Estonian Journal of Military Studies, Vol. 2018, Issue 7.

Sukhankin, S. (2016).Kaliningrad: Russia's stagnant enclave. European Council of Foreign Relations, 31 March 2016. https://www.ecfr.eu/article/commentary_kaliningrad_russias_stagnant_enclave_6052

Veebel, V. (2015). Russian Propaganda, Disinformation, and Estonia's Experience. FPRI, 4 October 2015. https://www.fpri.org/article/2015/10/russian-propaganda-disinformation-and-estonias-experience/

Veebel, V. (2018). NATO options and dilemmas for deterring Russia in the Baltic States. Defence Studies, 18(2), 229251.

Veebel, V. (2019). European Union as normative power in the Ukrainian-Russian conflict. International Politics, 56(5), $1-16$.

Veebel, V., \& Markus, R. (2018). The bust, the boom and the sanctions in trade relations with Russia. Journal of International Studies, 11(1), 9-20.

Veebel, V., \& Ploom, I. (2018). The Deterrence Credibility of NATO and the Readiness of the Baltic States to Employ the Deterrence Instruments. Lithuanian Annual Strategic Review, 16(1), 171-200.

Williams, I, (2017). The Russia - NATO A2AD Environment. CSIS Missile Defence Project. https://missilethreat.csis.org/russia-nato-a2ad-environment/

Zemla, E., \& Turecki, K. (2018). Poland offers US up to USD 2B for permanent military base. 25 May 2018. https:/ /www.politico.eu/article/ nato-poland-offers-us-up-to-2-billion-for-permanent-american-militarybase/ 